\title{
Optimizing alfalfa productivity and persistence versus greenhouse gases fluxes in a continental arid region
}

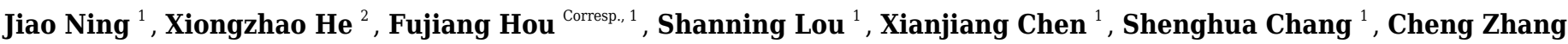 \\ 1 , Wanhe Zhu ${ }^{1}$ \\ ${ }^{1}$ State Key Laboratory of Grassland Agro-ecosystems, Key Laboratory of Grassland Livestock Industry Innovation Ministry of Agriculture, College of \\ Pastoral Agriculture Science and Technology, Lanzhou University, Lanzhou, Gansu, China \\ ${ }^{2}$ School of Agriculture and Environment, College of Science, Massey University, Palmerston North, New Zealand \\ Corresponding Author: Fujiang Hou \\ Email address: cyhoufj@Izu.edu.cn
}

Alfalfa in China is mostly planted in the semi-arid or arid Northwest inland regions due to its ability to take up water from deep in the soil and to fix atmospheric N2 which reduces $\mathrm{N}$ fertilizer application. However, perennial alfalfa may deplete soil water due to uptake and thus aggravate soil desiccation. The objectives of this study were (1) to determine the alfalfa forage yield, soil property [soil temperature (ST), soil water content (SWC), soil organic carbon (SOC) and soil total nitrogen (STN)] and greenhouse gas [GHG: methane $\left(\mathrm{CH}_{4}\right)$, nitrous oxide $\left(\mathrm{N}_{2} \mathrm{O}\right)$, and carbon dioxide $\left(\mathrm{CO}_{2}\right)$ ] emissions affected by alfalfa stand age and growing season, (2) to investigate the effects of soil property on GHG emissions, and (3) to optimize the alfalfa stand age by integrating the two standard criteria, the forage yield and water use efficiency, and the total $\mathrm{GHG}$ efflux $\left(\mathrm{CO}_{2}\right.$-eq). This study was performed in alfalfa fields of different ages (2, 3, 5 and 7 year old) during the growing season (from April to October) in a typical salinized meadow with temperate continental arid climate in the Northwest inland regions, China. Despite its higher total GHG efflux (CO2-eq), the greater forage yield and water use efficiency with lower GElhay and high $\mathrm{CH} 4$ uptake in the 5-year alfalfa stand suggested an optimal alfalfa stand age of 5 years. Results show that ST, SOC and RBM alone had positive effects (except RBM had no significant effect on $\mathrm{CH} 4$ effluxes), but SWC and STN alone had negative effects on GHG fluxes. Furthermore, results demonstrate that in arid regions SWC superseded ST, SOC, STN and RBM as a key factor regulating GHG fluxes, and soil water stress may have led to a net uptake of $\mathrm{CH} 4$ by soils and a reduction of $\mathrm{N} 2 \mathrm{O}$ and $\mathrm{CO} 2$ effluxes from alfalfa fields. Our study has provided insights into the determination of alfalfa stand age and the understanding of mechanisms regulating GHG fluxes in alfalfa fields in the continental arid regions. This knowledge is essential to decide the alfalfa retention time by considering the hay yield, water use efficiency as well as GHG emission. 


\section{Optimizing alfalfa productivity and persistence versus greenhouse gases}

\section{2 fluxes in a continental arid region}

4 Jiao Ning ${ }^{1}$, Xiong Z. He ${ }^{2}$, Fujiang Hou ${ }^{1}$, Shanning Lou ${ }^{1}$, Xianjiang Chen ${ }^{1}$, Shenhua Chang ${ }^{1}$, 5 Chen Zhang $^{1}$ \& Wanhe Zhu ${ }^{1}$

$7 \quad{ }^{1}$ State Key Laboratory of Grassland Agro-ecosystems, Key Laboratory of Grassland Livestock

8 Industry Innovation Ministry of Agriculture, College of Pastoral Agriculture Science and

9 Technology, Lanzhou University, Lanzhou, Gansu, China

$10{ }^{2}$ School of Agriculture and Environment, College of Science, Massey University, Palmerston

11 North, New Zealand

12

13 Corresponding Author:

14 Fujiang Hou ${ }^{1}$

15768 West Jiayuguan Road, Lanzhou, Gansu Province, 730000, China.

16 E-mail address: cyhoufj@,lzu.edu.cn

\section{ABSTRACT}

Alfalfa in China is mostly planted in the semi-arid or arid Northwest inland regions due to its ability to take up water from deep in the soil and to fix atmospheric $\mathrm{N}_{2}$ which reduces $\mathrm{N}$ fertilizer application. However, perennial alfalfa may deplete soil water due to uptake and thus aggravate soil desiccation. The objectives of this study were (1) to determine the alfalfa forage yield, soil property [soil temperature (ST), soil water content (SWC), soil organic carbon (SOC) and soil total nitrogen (STN)] and greenhouse gas 
24 [GHG: methane $\left(\mathrm{CH}_{4}\right)$, nitrous oxide $\left(\mathrm{N}_{2} \mathrm{O}\right)$, and carbon dioxide $\left.\left(\mathrm{CO}_{2}\right)\right]$ emissions affected by alfalfa

25 stand age and growing season, (2) to investigate the effects of soil property on GHG emissions, and (3) to

26 optimize the alfalfa stand age by integrating the two standard criteria, the forage yield and water use

27 efficiency, and the total $\mathrm{GHG}$ efflux $\left(\mathrm{CO}_{2}\right.$-eq).

28 This study was performed in alfalfa fields of different ages (2, 3, 5 and 7 year old) during the growing

29 season (from April to October) in a typical salinized meadow with temperate continental arid climate in

30 the Northwest inland regions, China.

31 Despite its higher total GHG efflux ( $\mathrm{CO}_{2}$-eq), the greater forage yield and water use efficiency with lower

32 GEIhay and high $\mathrm{CH}_{4}$ uptake in the 5-year alfalfa stand suggested an optimal alfalfa stand age of 5 years.

33 Results show that ST, SOC and RBM alone had positive effects (except RBM had no significant effect on

$34 \mathrm{CH}_{4}$ effluxes), but SWC and STN alone had negative effects on GHG fluxes. Furthermore, results

35 demonstrate that in arid regions SWC superseded ST, SOC, STN and RBM as a key factor regulating

36 GHG fluxes, and soil water stress may have led to a net uptake of $\mathrm{CH}_{4}$ by soils and a reduction of $\mathrm{N}_{2} \mathrm{O}$

37 and $\mathrm{CO}_{2}$ effluxes from alfalfa fields.

38 Our study has provided insights into the determination of alfalfa stand age and the understanding of mechanisms regulating GHG fluxes in alfalfa fields in the continental arid regions. This knowledge is essential to decide the alfalfa retention time by considering the hay yield, water use efficiency as well as GHG emission.

Keywords Arid climate, Stand age, Forage yield, Water use efficiency, Methane, Carbon dioxide, Nitrous oxide, Soil total nitrogen

\section{INTRODUCTION}

Alfalfa (Medicago Sativa L.) is the most widely grown perennial forage legume around the world (Yang et al., 2008). Since 2011, alfalfa planting has been gradually increased to meet the increasing demand for livestock production (Wang, Hansen \& Xu, 2016). The increasing demand of alfalfa has great potential to 
49

50

change the structure and function of the farming systems but has positive and negative influences. First, alfalfa with rhizobia, the root-dwelling symbiotic bacteria, can fix atmospheric $\mathrm{N}_{2}$ (Peterson \& Russelle, 1991) and thus reduce $\mathrm{N}$ fertilizer applications. Secondly, due to its strong ability to take up water (Wan et al., 2008), the alfalfa is mostly ( $>75 \%)$ planted in the Northwest inland regions with an arid or semiarid climate in or around the Loess Plateau of China (Hu \& Cash, 2009; Wang, Hansen \& Xu, 2016); however, alfalfa has a much higher water requirement than other crops which may deplete soil water and aggravate soil desiccation in long-term stands (Guan et al., 2013; Zhu et al., 2016). For example, McCallum, Peoples \& Connor (2000) reported that in Australia soil profiles under alfalfa-based perennial fields remain consistently drier throughout the year compared with continuous annual cropping. After eight years of alfalfa cultivation on the north edge of Loess Plateau, China, four to five years are required to restore soil water condition to the initial level (Du, Wang \& Long, 1999a), imposing a negative effect on the growth of subsequent crops. Moreover, the forage yield as well as the water use efficiency usually decrease after four to seven successive growing years (Du, Long \& Wang, 1999b; Zhang et al., 2004; Cheng, Wan \& Wang, 2005; Jia et al., 2009). Therefore, determination of the optimal cultivation ages of alfalfa is critical to avoid over-consumption of soil water by balancing the forage yield and water use efficiency.

Another concern with alfalfa is that the possible rhizobial denitrification may result in an increase of greenhouse gas (GHG, mainly the nitrous oxide $\mathrm{N}_{2} \mathrm{O}$, methane $\mathrm{CH}_{4}$, and carbon dioxide $\mathrm{CO}_{2}$ ) emissions (O'Hara \& Daniel, 1985). It is well known that $\mathrm{N}_{2} \mathrm{O}$ effluxes are driven by nitrification (oxidation of $\mathrm{NH}_{4}{ }^{+}$to $\mathrm{NO}_{3}{ }^{-}$via $\mathrm{NO}_{2}{ }^{-}$) under aerobic conditions and denitrification (reduction of $\mathrm{NO}_{3}{ }^{-}$to $\mathrm{N}_{2} \mathrm{O}$ and $\mathrm{N}_{2}$ ) under anaerobic conditions (Ussiri \& Lal, 2012; Oertel et al., 2016). $\mathrm{CO}_{2}$ release from soils is the subsequent results of soil respiration of both root and anaerobic and aerobic microbes (Oertel et al., 2016), where root respiration may contribute average up to about $50 \%$ of the total soil respiration depending on the season and vegetation type (Hanson et al., 2000). $\mathrm{CH}_{4}$ in soils is produced by methanogenesis under anaerobic conditions and is consumed by methanotrophic microorganisms that use $\mathrm{O}_{2}$ and $\mathrm{CH}_{4}$ for their metabolism under aerobic conditions (Smith et al., 2003; Dutaur \& Verchot, 2007; 
Gao et al., 2014). Thus, whether soil is a net source or sink for $\mathrm{CH}_{4}$ depends on the relative rates of methanogenic and methanotrophic activity (Tate, 2015; Tian et al., 2016). GHG fluxes are mediated by both biotic (e.g., microbial activity and root respiration) (Kitzler et al., 2006; Singh et al., 2010; Butterbach-Bahl et al., 2013) and abiotic (e.g., soil temperature, moisture, and soil carbon and nitrogen) factors (Kitzler et al., 2006; Singh et al., 2010; Butterbach-Bahl et al., 2013). Heretofore, how these factors influence GHG fluxes or which one is the most important factor influencing GHG fluxes in the arid continental regions is still not clear.

Previous studies on optimizing alfalfa stand age usually consider only two factors, the yield of alfalfa hay and water use efficiency, especially in the arid or semi-arid regions (e.g., Zhang et al., 2004; Cheng, Wan \& Wang, 2005; Fan et al., 2016) but ignores greenhouse gas (GHG) effluxes. In contrast, other studies studies investigate GHG effluxes from alfalfa fields of different stand ages (e.g., Zhong, Nelson \& Lemke, 2011; Uzoma et al., 2015; Burger et al., 2016) but do not measure alfalfa productivity; furthermore, those studies usually only consider $\mathrm{N}_{2} \mathrm{O}$ effluxes due to the $\mathrm{N}_{2}$ fixation of alfalfa. So far only a few studies on GHG effluxes from alfalfa fields have included $\mathrm{CH}_{4}, \mathrm{CO}_{2}$ and $\mathrm{N}_{2} \mathrm{O}$ in analyses (e.g., Chaves et al., 2006; Ellert \& Janzen, 2008).

In this study, we estimated the persistence of alfalfa in an arid continental region with respect to the tradeoffs between hay yield, water use efficiency, and GHG effluxes as affected by soil properties. The approach was to integrate the forage yield and water use efficiency with total GHG efflux $\left(\mathrm{CO}_{2}\right.$-eq) and GHG efflux $\left(\mathrm{CO}_{2}\right.$-eq) per unit hay yield. We then investigated the dynamics of soil properties (i.e., soil temperature, water content, organic carbon and total nitrogen), root biomass and $\mathrm{CH}_{4}, \mathrm{CO}_{2}$ and $\mathrm{N}_{2} \mathrm{O}$ fluxes during the growing seasons, and finally analyzed the influence of soil properties and root biomass on GHG fluxes. Results from this study will improve our understanding in GHG effluxes in the arid areas and provide essential information to develop strategies for alfalfa field management.

\section{METHODS}


100

101

102

103

104

105

106

107

108

109

110

111

112

113

114

115

116

117

118

119

120

121

122

123

124

125

\section{Study site and alfalfa field}

The study was carried out in Grassland Agricultural Trial Station of Lanzhou University (latitude 39 $15^{\prime}$

$\mathrm{N}$, longitude $\left.100^{\circ} 02^{\prime} \mathrm{E}\right)$, Gansu Province, China. The field ( $\left.\approx 280 \mathrm{ha}\right)$ used in this study is $1,390 \mathrm{~m}$ above the sea level and classified as a typical salinized meadow with temperate continental arid climate in the Northwest inland regions (Zhu et al., 1997). The mean annual precipitation is about $123 \mathrm{~mm}$ with $\geq 65 \%$ occurring during the growing seasons from April to October (Nobuyuki et al., 2018). Irrigation is necessary and usually applied bimonthly during the growing seasons with a rate of $120 \mathrm{~mm}$ respectively in April, June or August in the study site. The annual mean air temperature is $7.6^{\circ} \mathrm{C}$ (from $-28^{\circ} \mathrm{C}$ between December and February to $38^{\circ} \mathrm{C}$ between June and Mid-August). The soil $\mathrm{pH}$ value is about 8.0 , and the soil at the study site is classified as Aquisalids according to USDA soil taxonomy (Zhu et al., 1997).

To optimize the alfalfa stand ages in relation to biomass, soil properties and GHG effluxes, we used a Randomized Complete Block design in 2014. A long-term established forage study with differing stand ages was used for this experiment, and data collected for this experiment took place over one year (Zhu et al., 1997; Nobuyuki et al., 2018). There were three blocks (about 2.3 ha for each block) and each block was evenly divided into four subblocks, four stand age treatments (i.e., 2, 3, 5 and 7 years old, sown in late August 2012, 2011, 2009 and 2007, respectively) were randomly assigned into each subblock. For each subblock, three sampling plots (30 m width and of $100 \mathrm{~m}$ length) were randomly set up for forage harvest, and soil and GHG sampling.

\section{Alfalfa biomass and soil property}

To determine alfalfa productivity of different stage ages, one quadrat $(1 \mathrm{~m} \times 1 \mathrm{~m})$ in each sampling plot was randomly selected and the hay yield was measured by cutting above-ground biomass during early blooming periods (10 June, 20 July and 01 October). To measure the under-ground root biomass (RBM), another quadrat of the same size in each sampling plot was randomly selected, RBM was collected by digging $30 \mathrm{~cm}$ depth after gas collection (see next section for details). The harvested materials were ovendried at $60^{\circ} \mathrm{C}$ for 48 hours, and then weighted. 
126 To determine the soil characteristics in relation to field stage age, we also randomly selected two

127 sampling sites in each sampling plot, and soil samples were collected at a 0-10 $\mathrm{cm}$ depth using the bucket 128 auger (5 cm diameter) after gas collection (see next section for details). Soil samples were naturally dried 129 then extracted by passing through a $0.25-\mathrm{mm}$ sieve. Soil organic carbon (SOC) was measured by Chromic 130 acid REDOX titration (Nelson \& Sommers, 1996). Soil total nitrogen (STN) was determined following 131 the methods of Bremner \& Mulvaney (1982). Meanwhile, two cores ( $8.4 \mathrm{~cm}$ diameter $\times 6 \mathrm{~cm}$ length) 132 were sampled by inserting soil profile of $0-10 \mathrm{~cm}$ depth in each quadrat and cores were dried at $105^{\circ} \mathrm{C}$ for 13348 hours. The soil water content (SWC) was then estimated as: (original wet weight - soil dry weight)/soil 134 volume.

\section{GHG efflux}

137 GHG effluxes from soils are more likely to occur in spring, summer and autumn than in winter (Liu, 138 Wang \& Xu, 2010), thus GHG samplings were only carried out during the growing seasons of April, June, July, August and October in 2014. Two sampling sites were randomly selected in each sampling plot on 13 April. Gases were sampled four times (i.e., 5:00, 10:00, 14:00 and 18:00) for three successively sunny days in each mid-month, after removing the above-ground plant and litter (Liu et al., 2017). The mean GHG fluxes during the three successive days were treated as the average daily fluxes for that month. applied to detect its effect on GHG effluxes.

Gas was collected using a static opaque chamber $(30 \mathrm{~cm} \times 30 \mathrm{~cm} \times 30 \mathrm{~cm})($ Liu et al., 2017). For each sampling event, four gas samples were taken within 30 minutes at a time interval of 10 minutes (i.e., 0, 10, 20 and 30 minutes). The chamber was also equipped with an electronic thermometer. The air temperature inside the chamber was recorded during gas sampling and applied to calculate gas flux (see below). Soil temperature (ST) was also measured by a mercury thermometer inserted $5 \mathrm{~cm}$ into the soil at the sampling site before and after gas sampling and the mean temperature of the two measurements was

Gas concentration was measured within 24 hours, i.e., $\mathrm{CH}_{4}$ and $\mathrm{CO}_{2}$ were simultaneously analyzed 
152 by a $\mathrm{CH}_{4} / \mathrm{CO}_{2}$ Spektrum Analyser with syringe injection (Model No. 908-0011-0001, Los Gatos

153 Research, USA), and $\mathrm{N}_{2} \mathrm{O}$ was analyzed by a $\mathrm{N}_{2} \mathrm{O}$ Spektrum Analyser (Model No. 908-0015-0000, Los

154 Gatos Research, USA). According to Liu et al. (2017), the daily GHG fluxes were estimated as: $\mathrm{GHG}_{\text {daily }}$

$155=\left(a \times\right.$ flux $_{7: 00}+b \times$ flux $_{12: 00}+c \times$ flux $_{16: 00}+d \times$ flux $\left._{18: 00}\right)$, where $a, b, c$ and $d$ are the constant gas flux duration

156 (i.e., $a=11 \mathrm{~h}$ from 20:00 to 7:00, $b=5 \mathrm{~h}$ from 7:00 to 12:00, $c=4 \mathrm{~h}$ from 12:00 to 16:00, and $d=4 \mathrm{~h}$

157 from 16:00 and 20:00). The hourly GHG fluxes were thus estimated as: $\mathrm{GHG}_{\text {hourly }}=\mathrm{GHG}_{\text {daily }} / e$, where $e=$

15824 (number of hours per day); and the monthly GHG fluxes were then calculated as: $\mathrm{GHG}_{\mathrm{monthly}}=$

$159 \mathrm{GHG}_{\text {daily }} \times f$, where $f=30$ or 31 (number of days per month between April and October 2014). The total

160 gas flux during growing seasons was the sum of monthly fluxes (from April to October). Gas fluxes in

161 May and September were not measured and thus gap-filled using linear interpolation of the arithmetical

162 means of gas fluxes for the two close months (Chen et al., 2013).

163 The flux of GHG describes the change of gas in unit time in the sampling box. Generally, a positive

164 value indicates gas effluxes, and a negative value suggests gas absorption. The specific formula is (Liu et

165 al., 2017):

166

167

$$
F=\rho \frac{V}{A} \cdot \frac{P}{P_{0}} \cdot \frac{T_{0}}{T} \cdot \frac{d C t}{d t}
$$

where $F$ is the gas flux $\left(\mathrm{kg} / \mathrm{m}^{2} / \mathrm{h}\right), \rho$ is the gas density $\left(\mathrm{kg} / \mathrm{m}^{3}\right)$ under standard conditions $\left(\rho_{\mathrm{CO} 2}=1.965\right.$ $\mathrm{kg} / \mathrm{m}^{3}, \rho_{\mathrm{CH} 4}=0.715 \mathrm{~kg} / \mathrm{m}^{3}$ and $\rho_{\mathrm{N} 2 \mathrm{O}}=1.965 \mathrm{~kg} / \mathrm{m}^{3}$ respectively for $\mathrm{CO}_{2}, \mathrm{CH}_{4}$ and $\left.\mathrm{N}_{2} \mathrm{O}\right), V$ is chamber volume $\left(\mathrm{m}^{3}\right), A$ is the base area of the chamber $\left(\mathrm{m}^{2}\right), P$ is the atmospheric pressure $(\mathrm{kPa})$ of the sampling sites (approximately $85.48 \mathrm{kPa}$ at $1,390 \mathrm{~m}$ above sea level), $P_{0}$ is atmospheric pressure under standard conditions $(101.325 \mathrm{kPa}), T_{0}$ is the temperature under standard conditions $(273.15 \mathrm{~K}), T$ is the temperature $(\mathrm{K})$ inside the chamber, and $d C_{t} / d t$ is the average rate of concentration change with time (ppm $\left.\mathrm{min}^{-1}\right)$. The total GHG efflux is estimated as the global warming potential (GWP) for a 100-year time horizon, $\mathrm{CO}_{2}$-eq. One GWP of $\mathrm{CH}_{4}$ accounts for $25 \mathrm{CO}_{2}$-eq and one $\mathrm{GWP}$ of $\mathrm{N}_{2} \mathrm{O}$ for $298 \mathrm{CO}_{2}$-eq (Intergovernmental Panel on Climate Change [IPCC], 2006). Water use efficiency (WUE) was calculated according to Sun et al. (2018): WUE $=$ hay yield/(irrigation + precipitation $+\Delta \mathrm{SWC}_{\text {October-April }}$. The 
177 precipitation and irrigation from April to October 2014 was 70 and 360 mm, respectively. GHG efflux

178 intensity measuring the ratio of GHG effluxes per unit hay yield $\left(\mathrm{GEI}_{\text {hay }}\right)$ was also estimated according to

179 (Dyer et al., 2010): $\mathrm{GEI}_{\text {hay }}\left(\mathrm{kg} \mathrm{CO}_{2}\right.$-eq/kg hay) $=\mathrm{GHG}$ efflux/hay yield.

180

181

182

183

184

185

186

187

188

189

190

191

192

193

194

195

196

197

198

199

200

201

\section{Statistical analysis}

All other statistical analyses were conducted using SAS 9.4 (SAS Institute Inc., Cary, NC, USA). Results of a Shapiro-Wilk test (UNIVARIATE Procedure) indicated that data collected from this study were normally distributed. The difference in hay yield and WUE, and total GHG efflux $\left(\mathrm{CO}_{2}\right.$-eq) and $\mathrm{GEI}_{\text {hay }}$ between different stand ages were analyzed using least significant difference test (LSD test, GLM Procedure). The correlations of soil properties (i.e., ST, SWC, SOC, STN) and RBM to GHG effluxes were determined (CORR Procedure). The variations of soil properties and RBM and hourly GHG fluxes in response to alfalfa stand age (y, year) and seasonal progress (m, month) were analyzed using a general linear model (GLM Procedure): variation $=a+b \times \mathrm{m}+c \times \mathrm{m}^{2}+d \times \mathrm{y}+e \times \mathrm{y}^{2}+f \times \mathrm{m} \times \mathrm{y}$, where $a$ is intercept, and $b, c, d, e$ and $f$ are estimated regression coefficients. The significant coefficients were only included in the final model. A stepwise multiple regression analysis was applied to determine the possible effects of soil properties and $\mathrm{RBM}$ on $\mathrm{CH}_{4}, \mathrm{CO}_{2}$ and $\mathrm{N}_{2} \mathrm{O}$ fluxes (GLM Procedure) and the significant factors were only included in the final model. The proportional contributions of soil properties and $\mathrm{RBM}$ to $\mathrm{CH}_{4}$, $\mathrm{CO}_{2}$ and $\mathrm{N}_{2} \mathrm{O}$ fluxes were then calculated as: the sum of squares for each test factor, divided by the total sum of squares then multiplied by the regression coefficient (i.e., $R^{2}$ ) of the model.

\section{RESULTS}

\section{Alfalfa biomass, GHG fluxes and soil property in relation to alfalfa stand age}

Both total annual hay yield and WUE significantly increased with the stand age from 2 to 5 years then significantly decreased after which time $(L S D=0.50$ and 1.15 respectively for hay yield and WUE, $P<$ 0.0001 ) (Fig. 1). The first cutting respectively accounted for 56.1, 55.9, 55.2 and 59.5\% of total annual 
202 forage yield respectively from the 2-, 3-, 5- and 7-year-old fields, which was significantly greater than 203 that of the second or third cutting $(P<0.05)$.

204 The $\mathrm{GEI}_{\text {hay }}$ was significantly lower in 3- and 5-year-old fields than in 2- and 7-year-old ones $(L S D=$

205

206

207

208

209

210

211

212

213

214

215

216

217

218

219

220

221

222

223

224

225

226

227

$0.12, P<0.0001$ ) (Fig. 2A), and a significantly higher annual GHG efflux was detected in 5-year-old fields $(L S D=1.58, P=0.0030)($ Fig. $2 \mathrm{~B})$.

Alfalfa stand age had no significant effect on ST and SWC $\left(F_{1,56}=1.70\right.$ and 3.62 respectively for ST and SWC, $P>0.05$ ) (Fig. 3A-B). However, ST significantly increased from mid-spring (April) until summer (July) $\left(F_{1,57}=322.89, P<0.0001\right)$ and then significantly decreased after July $\left(F_{1,57}=358.83, P<\right.$ 0.0001) (Fig. 3A); while a reverse seasonal pattern was detected for SWC, i.e., it significantly decreased until July $\left(F_{1,57}=322.89, P<0.0001\right)$ then significantly increased $\left(F_{1,57}=358.83, P<0.0001\right)$ (Fig. 3B).

Both SOC and STN increased and peaked in 5-year-old fields $\left(F_{1,55}=5.28\right.$ and 13.76 respectively for SOC and STN, $P<0.05)$ then significantly decreased after which year $\left(F_{1,55}=5.75\right.$ and 14.08 respectively for SOC and STN, $P<0.05$ ) (Fig. 3C-D). However, SOC significantly increased with seasonal progress and peaked in July $\left(F_{1,55}=13.09, P=0.0006\right)$ after which month it significantly decreased $\left(F_{1,55}=13.61\right.$, $P=0.0005$ ) (Fig. 3C); but a reverse seasonal pattern was detected for STN, i.e., it significantly decreased from April to July $\left(F_{1,55}=7.78, P=0.0073\right)$ then significantly increased $\left(F_{1,55}=9.35, P=0.0034\right)$ (Fig. 3D).

Both stand age and growing season initially promoted the RBM $\left(F_{1,54}=268.71\right.$ and 29.96 respectively for stand age and month, $P<0.0001$ ) (Fig. 3E). But the RBM started to decline after August $\left(F_{1,54}=269.42, P<0.0001\right)$, and the decrease of RBM became slow $\left(F_{1,54}=24.00, P<0.0001\right)$ due to significant positive interaction between stand age and seasonal progress $\left(F_{1,54}=23.79, P<0.0001\right)$ (Fig. $3 \mathrm{E})$.

The dynamics of $\mathrm{CH}_{4}, \mathrm{CO}_{2}$ and $\mathrm{N}_{2} \mathrm{O}$ fluxes also largely depended on alfalfa stand age and season (Fig. 4). $\mathrm{CH}_{4}$ uptake was detected in the present study and it significantly increased when alfalfa aged up to 5 years old $\left(F_{1,54}=36.24, P<0.0001\right)$ then significantly decreased $\left(F_{1,54}=42.06, P<0.0001\right)$ (Fig.

4A). While $\mathrm{CH}_{4}$ uptake significantly decreased from April to July $\left(F_{1,54}=149.67, P<0.0001\right)$ and then 
228 significantly increased after July $\left(F_{1,54}=149.05, P<0.0001\right)$ (Fig. 4A). The $\mathrm{CH}_{4}$ uptake was generally

229 higher $\left(-15.4--25.0 \mu \mathrm{g} / \mathrm{m}^{2} / \mathrm{h}\right)$ in 5-year-old fields for a given month.

230 The seasonal and annual dynamics of $\mathrm{CO}_{2}$ and $\mathrm{N}_{2} \mathrm{O}$ effluxes were similar, i.e., the effluxes

231 significantly increased when alfalfa aged to 5 years old $\left(F_{1,55}=15.62\right.$ and 15.35 for $\mathrm{CO}_{2}$ and $\mathrm{N}_{2} \mathrm{O}$

232 respectively, $P<0.001)$ and the significantly decreased $\left(F_{1,55}=13.03\right.$ and 13.32 for $\mathrm{CO}_{2}$ and $\mathrm{N}_{2} \mathrm{O}$

233 respectively, $P<0.001)$; similarly the effluxes significantly increased since April $\left(F_{1,55}=322.37\right.$ and

234195.10 for $\mathrm{CO}_{2}$ and $\mathrm{N}_{2} \mathrm{O}$ respectively, $\left.P<0.001\right)$ and then significantly decreased after July $\left(F_{1,55}=\right.$

235363.12 and 200.82 for $\mathrm{CO}_{2}$ and $\mathrm{N}_{2} \mathrm{O}$ respectively, $P<0.001$ ) (Fig. 4B-C). The greatest effluxes of $\mathrm{CO}_{2}$

236 (i.e., $\left.551.1 \mathrm{mg} / \mathrm{m}^{2} / \mathrm{h}\right)$ and $\mathrm{N}_{2} \mathrm{O}\left(8.0 \mu \mathrm{g} / \mathrm{m}^{2} / \mathrm{h}\right)$ were estimated in 5-year-old fields in July.

237

238

GHG efflux in relation to soil property and root biomass

239

240

241

242

243

244

245

246

247

248

249

250

252

253

251 DISCUSSION

The $\mathrm{CH}_{4}$ uptake significantly decreased with increasing ST and SOC but increased with increasing SWC and STN (Table 1). While $\mathrm{CO}_{2}$ and $\mathrm{N}_{2} \mathrm{O}$ effluxes significantly increased with increasing $\mathrm{ST}$ and SOC but decreased with increasing SWC and STN (Table 1). RBM had no significant effect on $\mathrm{CH}_{4}$, whereas $\mathrm{CO}_{2}$ and $\mathrm{N}_{2} \mathrm{O}$ effluxes significantly increased with the increase of RBM (Table 1).

When both soil property and RBM were considered, SWC was the only factor that significantly affected $\mathrm{CH}_{4}$ fluxes (Table 2). While three factors (i.e., SWC, ST and SOC) significantly affected $\mathrm{CO}_{2}$ effluxes, and four factors (i.e., SWC, ST, SOC and RMB) significantly affected $\mathrm{N}_{2} \mathrm{O}$ effluxes (Table 2). SWC accounted for $\geq 65 \%$ variation of $\mathrm{CO}_{2}$ and $\mathrm{N}_{2} \mathrm{O}$ effluxes. ST explained about $15 \%$ variation of $\mathrm{CO}_{2}$ effluxes, which was 4.3 times less than did SWC but 3.5 times more than did SOC. For $\mathrm{N}_{2} \mathrm{O}$ effluxes, ST only accounted for only $<5 \%$ variation, which was 7.3 and 2.1 times less than did SWC and SOC, respectively, and RBM accounted for only $<2 \%$ of variation (Table 2 ).

52 A number of empirical studies have determined the optimal stand age of alfalfa in the semi-arid Loess Plateau and Inner Mongolia regions, while different experimental designs, field management and 
254 geographic locations could generate divergent conclusions. For example, when considering the forage

255 yield only, the optimal stand age varies from 3 to 5 years depending on the annual precipitation (i.e., 300

$256-500$ mm) (e.g., Du, Long \& Wang, 1999b; Zhang et al., 2004; Cheng, Wan \& Wang, 2005). Jia et al.

257 (2009) suggested that the optimal stand age should be 7 years if considering hay yield only but could be

258 up to 15 years when considering WUE alone. In the present study, we show that 5 years may be the

259 optimal alfalfa stand, for two reasons. First, both the hay yield and WUE were significantly greater in 5-

260 year-old alfalfa fields (Fig. 1). Second, although the significantly higher total annual GHG effluxes (Fig.

261 2B; also see Fig. 4B-C), the total annual GHG efflux rate per unit hay yield (i.e., $\mathrm{GEI}_{\text {hay }}$ ) was significantly

262 lower (Fig. 2A) and the net $\mathrm{CH}_{4}$ uptake was higher in the 5-year-old alfalfa fields (Fig. 4A). Therefore,

263 the net $\mathrm{CH}_{4}$ sink may have largely offset the alfalfa $\mathrm{CO}_{2}$ and $\mathrm{N}_{2} \mathrm{O}$ effluxes in the arid continental regions

264 (Fig. 4). To our knowledge, this is the first study providing evidence for the assessment of optimal crop

265 stage age integrating the total annual GHG effluxes and $\mathrm{GEI}_{\text {hay }}$.

266 Alfalfa stand age affecting soil GHG effluxes is mediated by changing soil properties. Many authors

267 have demonstrated that successive cropping alfalfa will elevate soil nutrient due to sequestering carbon

268 (C) and nitrogen (N) into soils and eliminating tillage (Halvorson Wienhold \& Black, 2002; Liang et al.

269 2003). Our results show that SOC and STN continuously increased when alfalfa aged up to 5 years old

270 (Fig. 3C-D), which agreed with previous studies (Xu, 2014; Cao et al., 2012). Alfalfa RBM also had a

271 similar seasonal and annual pattern as SOC (Fig. 3C and 3E). Because new root develops primarily in the

272 spring and root biomass increases as more $\mathrm{C}$ is fixed by the greater leaf areas associated with plant

273 regrowth, greater amounts of C are translocated to the root system (Lee \& Jose, 2003; Jiang \& Claude,

274 2006). However, root development and C-fixation may decline after extended dry periods, which

275 decreases SOC at the end of growing season (Fig. 3E). The lower STN content detected during the warm

276 seasons may attribute to the higher uptake of soil inorganic $\mathrm{N}$ by the growing plants. The decreasing

277 SOC, STN and RBM in the 7-year-old fields indicate a declining plant vitality (Zhang et al., 2004; Cheng,

278 Wan \& Wang, 2005; Jia et al., 2009; Xu, 2014) resulting in a lower forage yield (Fig. 1A).

279 Soil property change may influence the source and sink function of greenhouse gases (Oertel et al., 
280

281

282

283

284

285

286

287

288

289

290

291

292

293

294

295

296

297

298

299

300

301

302

303

304

305

2016). Amount the abiotic factors, soil temperature and moisture are the two major drivers regulating GHG effluxes mainly via soil respiration and microbial activity (Kitzler et al., 2006; Singh et al., 2010; Butterbach-Bahl et al., 2013). As reported in a study in alfalfa fields in the dry Loess Plateau in China (Xu, 2014), we found that increasing soil temperature promoted $\mathrm{CO}_{2}$ and $\mathrm{N}_{2} \mathrm{O}$ effluxes and suppressed $\mathrm{CH}_{4}$ uptake (Table 2; Figs. 3 and 4). These results agree with the general conclusions of previous studies (e.g., Kitzler et al., 2006; Singh et al., 2010; Butterbach-Bahl et al., 2013; Zhu et al., 2016). Therefore, it may be prevalent that $\mathrm{CO}_{2}$ and $\mathrm{N}_{2} \mathrm{O}$ effluxes start to increase in spring and peak in summer (Fig. 4), because the soil warming promotes soil respiration rate via microbial activity (e.g., faster growth rate and substrate use rate) (Kitzler et al., 2006; Singh et al., 2010; Xu, 2014).

Unlike temperature, moisture influences GHG fluxes via changing GHG diffusion rate and oxygen availability or regulating microbial communities because they require water for physiological activities (Singh et al., 2010). However, each soil type may have a specific soil moisture that optimizes GHG fluxes (Schindlbacher et al., 2004). When moisture exceeds the optimum level, gas transport is restricted (Schaufler et al. 2010; Kim et al. 2012), leading to anaerobic conditions; whereas suboptimal moisture levels will limit GHG fluxes due to water stress of soil microbes (Schindlbacher et al., 2004; Kitzler et al., 2006). By following this line, it may be predicted that at the arid conditions such as that of our experiment where SWC is below the optimum level, increasing SWC will promote $\mathrm{CH}_{4}$ uptake and $\mathrm{CO}_{2}$ and $\mathrm{N}_{2} \mathrm{O}$ emission as it elevates diffusivity of oxygen $\left(\mathrm{O}_{2}\right)$ in soils which is essential for soil respiration and bacterial nitrification and methanotrophy under aerobic conditions. Our results partially support the assumptions. Increased SWC induced higher $\mathrm{CH}_{4}$ uptake (Figs. 3B and 4A; Tables 1 and 2), agreeing with Dutaur and Verchot (2007) that methanotrophy is a dominant process in upland dry soils and there is thus a net uptake of $\mathrm{CH}_{4}$ by soils. However, our results show that $\mathrm{CO}_{2}$ and $\mathrm{N}_{2} \mathrm{O}$ emission decreased with increasing of SWC (Figs. 3B and 4B; Tables 1 and 2). Therefore, it is supposed that different GHGs have various thresholds of SWC invoking gas emission in arid regions, which are warranted for future studies. Beside the main abiotic drivers of soil moisture and temperature, agricultural GHG fluxes are directly mediated by biotic factors including root respiration and microbial activity (Kitzler et al., 2006; 
306

307

308

309

310

311

312

313

314

315

316

317

318

319

320

321

322

323

324

325

326

327

328

329

330

331

Singh et al., 2010; Butterbach-Bahl et al., 2013) of which are regulated by root biomass and soil nutrient such as carbon and nitrogen (e.g., Schindlbacher et al., 2004; Wang, Peng \& Fang, 2010; Oertel et al., 2016). Indeed, some researchers have reported the positive correlations between soil respiration, RBM and SOC (Lee \& Jose, 2003; Jiang \& Claude, 2006) and between $\mathrm{N}_{2} \mathrm{O}$ efflux and SOC (Xu, 2014). Our results indicate that increasing SOC and RBM significantly elevated $\mathrm{CO}_{2}$ and $\mathrm{N}_{2} \mathrm{O}$ effluxes (Table 1). According to $\mathrm{Xu}$ (2014), the greater GHG effluxes in 5-year-old fields (Figs. 2B, 3B, and 3C) may partially attribute to the higher microbial abundance and activity and root respiration owing to the higher soil nutrient and RBM (Fig. 3).

When compared the annual dynamics of STN (Fig. 3D) with that of $\mathrm{N}_{2} \mathrm{O}$ effluxes (Fig. 4C), we may assume that increasing STN (organic and inorganic $\mathrm{N}$ ) in soils may enhance $\mathrm{N}_{2} \mathrm{O}$ effluxes via the biological processes of nitrification or denitrification (Xu, 2014; MacDonald, Farrell \& Baldock, 2016;

Oertel et al., 2016). However, our findings do not support the above notion, rather STN had a significantly negative effect on $\mathrm{N}_{2} \mathrm{O}$ effluxes (Table 1). In agricultural systems, plants only take up inorganic $\mathrm{N}$ (i.e., $\mathrm{NO}_{3}^{-}-\mathrm{N}$ and $\left.\mathrm{NH}_{4}{ }^{+}-\mathrm{N}\right)($ Schmidt, Nasholm \& Rentsch, 2014), but may use organic $\mathrm{N}$ through the processes of mineralization (bacteria digest organic material and release $\mathrm{NH}_{4}{ }^{+}-\mathrm{N}$ ) and nitrification (bacteria convert $\mathrm{NH}_{4}{ }^{+}-\mathrm{N}$ to $\mathrm{NO}_{3}{ }^{-}-\mathrm{N}$ ) (Schmidt, Nasholm \& Rentsch, 2014; Fernandez \& Kaiser, 2018). The causes of negative effect of STN on $\mathrm{N}_{2} \mathrm{O}$ effluxes may be that the increasing STN (Fig. 3D) promotes the uptake of $\mathrm{NH}_{4}{ }^{+}-\mathrm{N}$ and $\mathrm{NO}_{3}{ }^{-}-\mathrm{N}$ by plants for growth (Ghimire, Norton \& Pendall, 2013), which reduces $\mathrm{NH}_{4}{ }^{+}-\mathrm{N}$ available for microbial nitrification and results in less $\mathrm{N}_{2} \mathrm{O}$ effluxes.

Considering the climate conditions in this study, the net $\mathrm{N}_{2} \mathrm{O}$ effluxes in the alfalfa fields may attribute to the processes of nitrification under aerobic conditions.

Although ST, SWC, SOC, STN and RBM alone had significant positive or negative effect on GHG effluxes (except RBM had no significant effect on $\mathrm{CH}_{4}$ effluxes, Table 1), STN had little impact on GHG effluxes, and increasing RBM could significantly elevate $\mathrm{N}_{2} \mathrm{O}$ efflux, but its impact was very small, i.e. explained $<2 \%$ variation (Table 2). Agreeing with that of Schindlbacher et al. (2004) and Oertel et al. (2016), the flux rates of $\mathrm{N}_{2} \mathrm{O}$ and $\mathrm{CO}_{2}$ largely depend on ST, SWC and SOC (Table 2). Generally, as 
332 discussed above an increase of soil temperature will lead to greater effluxes and soil respiration rates as a

333 positive feedback response of increased microbial metabolism (Kitzler et al., 2006; Singh et al., 2010;

334 Butterbach-Bahl et al., 2013; Oertel et al., 2016). However, Fowler et al. (2009) stated that the positive

335 temperature impact could be limited by soil water stress, as water is needed as a transport medium for

336 nutrients required by microbes. In the current study, $\mathrm{N}_{2} \mathrm{O}$ and $\mathrm{CO}_{2}$ effluxes were more sensitive to SWC

337 than to $\mathrm{ST}$ and $\mathrm{SOC}$, and $\mathrm{CH}_{4}$ efflux responded only to SWC (Table 2).

\section{CONCLUSIONS}

340

341

342

343

344

345

346

347

348

349

350

351

\section{ACKNOWLEDGEMENTS}

353

Based on the forage yield, WUE, GHG efflux $\left(\mathrm{CO}_{2}\right.$-eq $)$ and $\mathrm{GEI}_{\text {hay }}$, we found that in the arid inland regions the optimal alfalfa stand age is 5 years. This knowledge is helpful in decision of alfalfa retention time based on the maximum benefit by considering the hay yield, water use efficiency, GHG emission as well as the cost of field establishment of alfalfa. Our results also indicate that in the arid regions with higher soil water stress, SWC overrides ST, SOC and RBM as a key factor regulating GHG fluxes and increasing SWC leads to an increase of net uptake of $\mathrm{CH}_{4}$ by soils and a reduction of $\mathrm{N}_{2} \mathrm{O}$ and $\mathrm{CO}_{2}$ effluxes from the alfalfa fields. Irrigation is required for alfalfa growing in the arid regions, while it also has significant impacts on GHG emission (Dutaur \& Verchot, 2007; Schaufler et al., 2010; Ussiri \& Lal, 2013; Burger et al., 2016). Therefore, future researches on the dynamics of GHG fluxes affected by irrigation (i.e., frequency, timing, and amount of irrigation water used) are warranted to develop strategies for GHG mitigation, increasing alfalfa forage yield and prolonging alfalfa persistence in the continental arid regions.

Financial support for this research was provided by Strategic Priority Research Program of Chinese Academy of Science (XDA20100102), National Key Basic Research Program of China (2014CB138706), Changjiang Scholars and Innovative Research Team in University (IRT17R50), and The 111 project (B12002). We thank two anonymous reviewers and the handling editor for their 
357

358

359

360

361

362

363

364

constructive comments on earlier versions, which have significantly improved the paper. We also are grateful to Dr Charles West (Texas Tech University) for his valuable comments and time spent editing the English of a previous version of the paper.

\section{REFERENCES}

Bremner JM, Mulvaney CS. 1982. Nitrogen-total. In Page AL, Miller RH, Keeney DR (Eds.) Methods of soil analysis: part 2-chemical and microbiological properties (pp. 595-624). Soil science society of America journal, Madison, Wisconsin

Burger M, Haden VR, Chen H, Six J, Horwath WR. 2016. Stand age affects emissions of $\mathrm{N}_{2} \mathrm{O}$ in flood-irrigated alfalfa: a comparison of field measurements, DNDC model simulations and IPCC Tier 1 estimates. Nutrient Cycling in Agroecosystems 106(3):335-345

Butterbach-Bahl K, Baggs EM, Dannenmann M, Kiese R, Zechmeister-Boltenstern S. 2013. Nitrous oxide emissions from soils: how well do we understand the processes and their controls? Philosophical Transactions of the Royal Society 368(1621): 20130122.

Cao J, Li X, Kong X, Zed R, Dong L. 2012. Using alfalfa (Medicago sativa) to ameliorate salt-affected soils in Yingda irrigation district in Northwest China. Acta Ecologica Sinica 32(2):68-73

Chaves AV, Thompson LC, Iwaasa AD, Scott SL, Olson ME, Benchaar C, Veria DM, McAllister TA. 2006. Effect of pasture type (alfalfa vs. grass) on methane and carbon dioxide production by yearling beef heifers. Canadian Journal of Animal Science 86(3):409-418

Chen W, Wolf B, Zheng X, Yao Z, Butterbach-Bahl K, Brüggemann N, Han S, Liu C, Han X. 2013. Carbon dioxide emission from temperate semiarid steppe during the non-growing season. Atmospheric Environment 64:141-149

Cheng J, Wan H, Wang J. 2005. Alfalfa growth and its relation with soil water status in loess hilly and gully region. The Journal of Applied Ecology 16(3):435-438

Du S, Wang L, Long M. 1999a. Soil water dynamics and yield response on lucerne in dry land farming in mountain region, Northern of Ninxia. Pratacultural Science 13(1)16-18

Du S, Long M, Wang L.1999b. Study on soil moisture and yield dynamic of arid alfalfa grassland in mountain area 
of southern Ningxia. Pratacultural Science 16(1)12-17

Dutaur L, Verchot LV. 2007. A global inventory of the soil $\mathrm{CH}_{4}$ sink. Global Biogeochemical Cycles 21(4)1-9

Dyer JA, Verge XPC, Desjardins RL, Worth DE. 2010. The protein-based GHG emission intensity for livestock products in Canada. Journal of Sustainable Agriculture 34(6):618-629

Ellert BH, Janzen HH. 2008. Nitrous oxide, carbon dioxide and methane emissions from irrigated cropping systems as influenced by legumes, manure and fertilizer. Canadian Journal of Soil Science 88(2):207-217

Fan J, Du Y, Wang B, Turner NC, Wang T, Abbott LK, Stefanova K, Siddique K, Li F. 2016. Forage yield, soil water depletion, shoot nitrogen and phosphorus uptake and concentration, of young and old stands of alfalfa in response to nitrogen and phosphorus fertilisation in a semiarid environment. Field Crops Research 198: $247-257$

Fernandez FG, Kaiser DE. 2018. Understanding nitrogen in soils. Retrieved from https://extension.umn.edu/nitrogen/understanding-nitrogen-soils\#organic-n-sources-760712 (accessed 05 August 2018)

Fowler D, Pilegaard K, Sutton MA, Ambus P, Raivonen M, Duyzer J, Granier C. 2009. Atmospheric composition change: ecosystems-atmosphere interactions. Atmospheric Environment 43(33):5193-5267

Gao B, Ju X, Su F, Meng Q, Oenema O, Christie P, Chen X, Zhang F. 2014. Nitrous oxide and methane emissions from optimized and alternative cereal cropping systems on the North China Plain: a two-year field study. Science of The Total Environment 47:112-114

Ghimire R, Norton JB, Pendall E. 2013. Alfalfa-grass biomass, soil organic carbon, and total nitrogen under different management approaches in an irrigated agroecosystem. Plant and Soil, 374(1-2):173-184

Guan X, Zhang X, Turner N, Xu B, Li F. 2013. Two perennial legumes (Astragalus adsurgens Pall. and Lespedeza davurica $\mathrm{S}$.) adapted to semiarid environments are not as productive as lucerne (Medicago sativa L.), but use less water. Grass \& Forage Science 68(3):469-478

Hanson PJ, Edwards NT, Garten CT, Andrews JA. 2000. Separating root and soil microbial contributions to soil respiration: a review of methods and observations. Biogeochemistry 48(1):115-146

Halvorson AD, Wienhold BJ, Black AL. 2002. Tillage, nitrogen, and cropping system effects on soil carbon sequestration. Soil Science Society of America Journal 66(3): 906-912

Hu Y, Cash D. 2009. Global status and development trends of alfalfa, Alfalfa management guide for Ningxia. 
United Nations Food and Agriculture Organization, China

Intergovernmental Panel on Climate Change (IPCC). 2006. IPCC guidelines for national 465 greenhouse gas inventories. Retrieved from https://www.ipcc-466 nggip.iges.or.jp/public/2006gl/index.html

Jia Y, Li F, Zhang Z, Wang X, Guo R, Siddique KH. 2009. Productivity and water use of alfalfa and subsequent crops in the semiarid Loess Plateau with different stand ages of alfalfa and crop sequences. Field Crops Research 114(1):58-65

Jiang X, Claude EB. 2006. Relationship between organic carbon concentration and potential pond bottom soil respiration. Aquacultural Engineering 35(2):147-151

Kim DG, Vargas R, Bond-Lamberty B, Turetsky MR. 2012. Effects of soil rewetting and thawing on soil gas fluxes: a review of current literature and suggestions for future research. Biogeosciences 9(7): 2459-2483

Kitzler B, Zechmeister-Boltenstern S, Holtermann C, Skiba U, Butterbach-Bahl K. 2006. Nitrogen oxides emission from two beech forests subjected to different nitrogen loads. Biogeosciences 3(3): 293-310

Kobayashi N, Hou F, Tsunekawa A, Chen X, Ichinohe T. 2018. Appropriate level of alfalfa hay in diets for rearing simmental crossbred calves in dryland China. Asian Australasian Journal of Animal Sciences 31(12):1-9

Lee KH, Jose S. 2003. Soil respiration, fine root production, and microbial biomass in cottonwood and loblolly pine plantations along a nitrogen fertilization gradient. Forest Ecology and Management 185(3):263-273

Liang B, McConkey BG, Schoenau J, Curtin D, Campell CA, Moulin AP, Lanford GP, Brandt SA. Wang H. 2003. Effect of tillage and crop rotations on the light fraction organic carbon and carbon mineralization in Chernozemic soils of Saskatchewan. Canadian Journal of Soil Science 83(1):65-72

Liu S, Wang C, Xu F. 2010. Soil effluxes of carbon dioxide, methane and nitrous oxide during non-growing season for four temperate forests in northeastern China. Acta Ecologica Sinica 30:4075-4084

Liu Y, Yan C, Matthew C, Wood B, Hou F. 2017. Key sources and seasonal dynamics of greenhouse gas fluxes from yak grazing systems on the Qinghai-Tibetan Plateau. Scientific Report 7:40857.

MacDonald L, Farrell M, Baldock J. 2016. The influence of increasing organic matter content on $\mathrm{N}_{2} \mathrm{O}$ emissions. Proceedings of the 2016 International Nitrogen Initiative Conference, "Solutions to improve nitrogen use efficiency for the world" Melbourne, Australia

McCallum MH, Peoples MB, Connor DJ. 2000. Contributions of nitrogen by field pea (Pisum sativum L.) in a 
440 continuous cropping sequence compared with a lucerne (Medicago sativa L.)-based pasture ley in the Victorian Wimmera. Australia Journal of Agricultural Research 51(1):13-22.

Nelson D, Sommers L. 1996. Total carbon, organic carbon and organic matter, part 3: chemical methods, Soil Science Society of America Book Series, Number 5. Soil Science Society America, Wisconsin

Oertel C, Matschullat J, Zurba K, Zimmermann F, Erasmi S. 2016. Greenhouse gas emissions from soils-a review. Chemie der Erde - Geochemistry - Interdisciplinary Journal for Chemical Problems of the Geosciences and Geoecology 76(3):327-352

O'Hara GW, Daniel RM. 1985. Rhizobial denitrification: a review, Soil Biology and Biochemistry 17, 1-9

Peterson TA, Russelle MP. 1991. Alfalfa and the nitrogen cycle in the Corn Belt. Journal of Soil Water Conservation 46:229-235.

Schaufler G, Kitzler B, Schindlbacher A, Skiba U, Sutton MA, Zechmeister-Boltenstern S. 2010. Greenhouse gas emissions from European soils under different land use: effects of soil moisture and temperature. European Journal of Soil Science 61(5): 683-696

Schindlbacher A, Zechmeister-Boltenstern S, Butterbach-Bahl K. 2004. Effects of soil moisture and temperature on $\mathrm{NO}, \mathrm{NO}_{2}$, and $\mathrm{N}_{2} \mathrm{O}$ emissions from European forest soils. Journal of Geophysical Research Atmospheres 109(17):29-31.

Schmidt S, Nasholm T, Rentsch D. 2014. Organic nitrogen. New Phytologist 203(1):29-31

Singh BK, Bardgett RD, Smith P, Reay DS. 2010. Microorganisms and climate change: terrestrial feedbacks and mitigation options. Nature Reviews Microbiology 8(11): 779-790.

Smith KA, Ball T, Conen F, Dobbie KE, Massheder J, Rey A. 2003. Exchange of greenhouse gases between soil and atmosphere: interactions of soil physical factors and biological processes. European Journal of Soil Science 54(4):779-791

Sun M, Ren A, Gao Z, Wang P, Mo F, Xue L, Lei M. 2018. Long-term evaluation of tillage methods in fallow season for soil water storage, wheat yield and water use efficiency in semiarid southeast of the loess plateau. Field Crops Research 218(9):24-32

Tate KR. 2015. Soil methane oxidation and land-use change-from process to mitigation. Soil Biology and Biochemistry 80:260-272

Tian H, Lu C, Ciais P, Michalak A, Canadell JG, Saikawa E, Huntzinger DN, Gurney KR, Stich S, Zhang B, 
468

469

470

471

472

473

474

475

476

477

478

479

480

481

Yang J, Bousquet P, Bruhwiler L, Chen G, Dlugokenky E, Friedlingstein P, Melillo J, Pan S, Poulter B, Prinn R, Sauniois M, Schwalm CR, Yang J. 2016. The terrestrial biosphere as a net source of greenhouse gases to the atmosphere. Nature 531(7593):225

Ussiri D, Lal R. 2013. Soil emission of nitrous oxide and its mitigation. Springer Netherlands

Uzoma KC, Smith W, Grant B, Desjardins RL, Gao X, Hanis K, Tenuta M, Goglio P, Li C. 2015. Assessing the effects of agricultural management on nitrous oxide emissions using flux measurements and the DNDC model. Agriculture, Ecosystems \& Environment 206:71-83

Wan S, Jia Z, Han Q, Yang B. 2008. Dry soil layer forming and soil moisture restoration of alfalfa grassland in the semi-humid region of the Loess Plateau. Acta Ecologica Sinica 28(3):164-170

Wang W, Peng S, Fang J. 2010. Root respiration and its relation to nutrient contents in soil and root and EVI among 8 ecosystems, northern China. Plant and Soil 333(1-2):391-401

Wang Q, Hansen J, Xu F. 2016. China's emerging dairy markets and potential impacts on U.S. alfalfa and dairy product exports. The 2016 Agricultural \& Applied Economics Association Annual Meeting. Boston, United States

Xu K. 2014. Soil carbon and nitrogen storage and greenhouse gas emission fluxes in alfalfa pasture with different planting years. Ningxia University, China

Yang S, Gao M, Xu C, Gao J, Deshpande S, Lin S, Roe BA, Zhu H. 2008. Alfalfa benefits from Medicago truncatula: the RCT1 gene from M. truncatula confers broad-spectrum resistance to anthracnose in alfalfa. Proceedings of the National Academy of Sciences 105(34):12164-12169

Zhang C, Hao M, Wei X, Wang X. 2004. Soil water distribution characteristics of alfalfa with different planting years in the gully region of the Loess Plateau. Plant Nutrition and Fertilizer Science 10(6):604-607

Zhong Z, Nelson LM, Lemke RL. 2011. Nitrous oxide emissions from grain legumes as affected by wetting/drying cycles and crop residues. Biology and Fertility of Soils 47(4):687-699

Zhu L, Zhang H, Gao X, Qi Y, Xu X. 2016. Seasonal patterns in water uptake for Medicago sativa grown along an elevation gradient with shallow groundwater table in Yanchi county of Ningxia, Northwest China. Journal of Arid Land 8(6): 921-934

Zhu X, Shen Y, Yan S, Zhao Y. 1997. The base research of Linze grassland ecological test station. Pratacultural Science 14(2):14-19

Peer) reviewing PDF | (2019:11:43325:1:1:NEW 17 Jan 2020) 


\section{Figure 1}

Mean ( \pm SE) annual hay yield (A) and water use efficiency (WUE) (B) in alfalfa fields of different stand ages.

For the total hay yield (A) or WUE (B), columns with the same uppercase letters are not significantly different $(P>0.05)$. For the hay yield of each cutting, columns with the same lowercase letters are not significantly different $(P>0.05)$. 


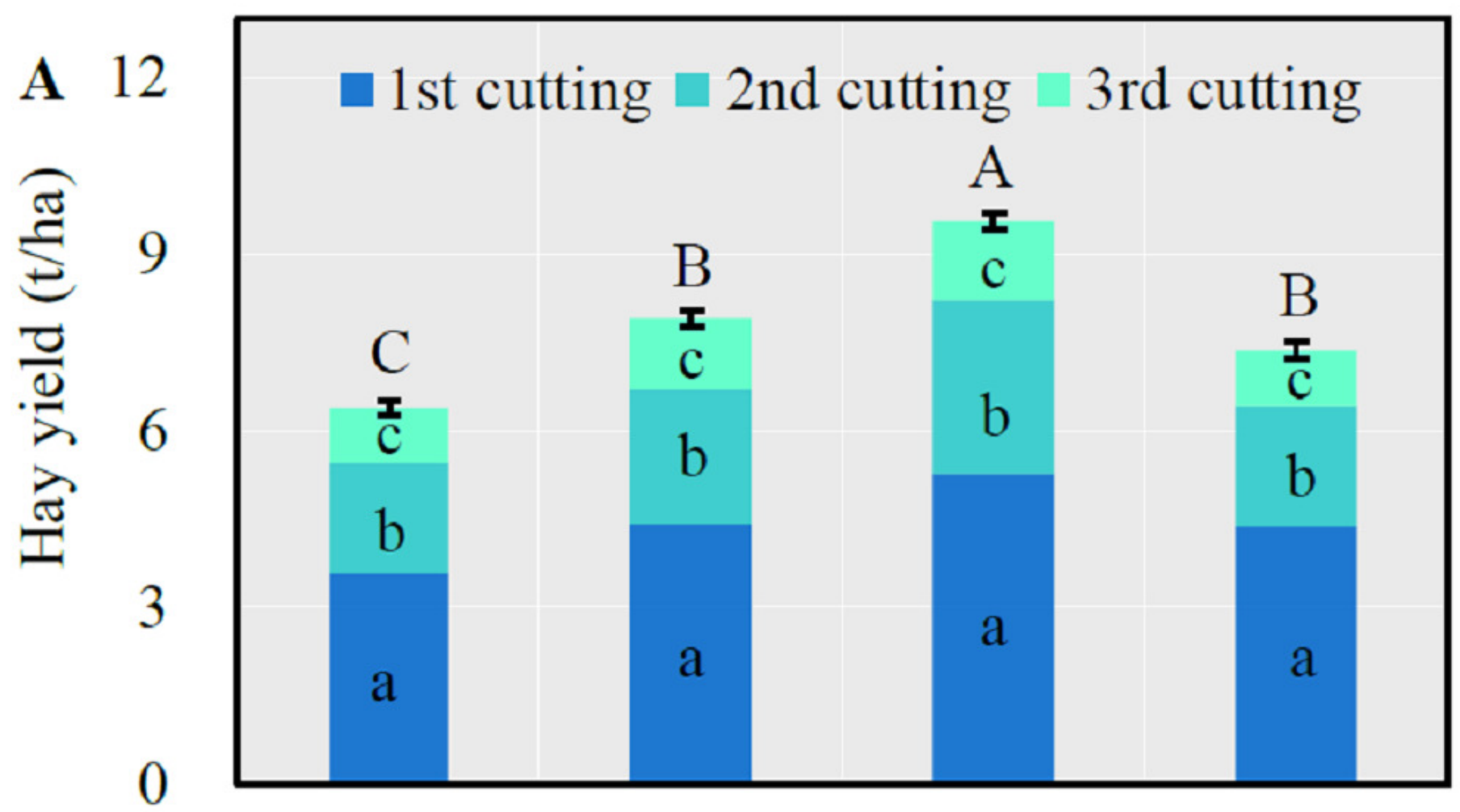

B 30

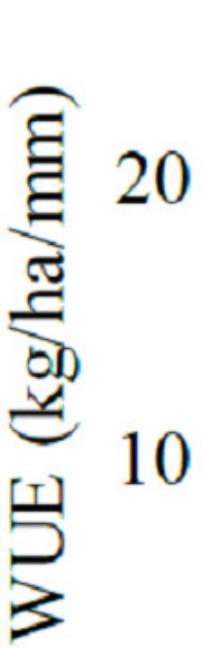

0

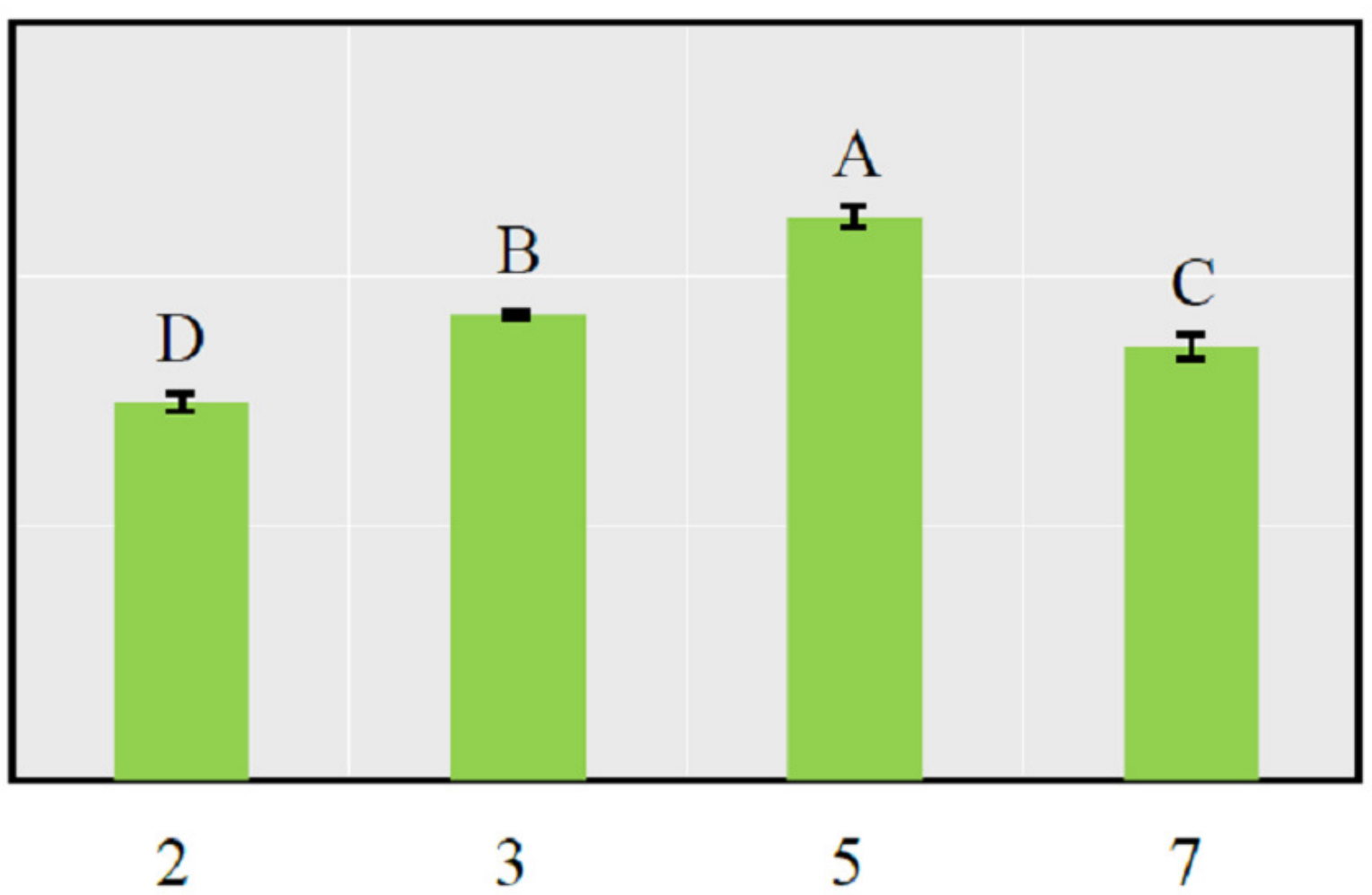

Stand age (years) 
Figure 2

The mean ( $\pm \mathrm{SE}$ ) GHG efflux $\left(\mathrm{CO}_{2}\right.$-eq) per unit hay yield $\left(\mathrm{GEI}_{\text {hay }}\right)(\mathrm{A})$ and total $\mathrm{GHG}$ efflux $\left(\mathrm{CO}_{2}\right.$-eq) $(\mathrm{B})$ in alfalfa fields of different stand ages.

Columns with the same lowercase letters are not significantly different $(P>0.05)$. 

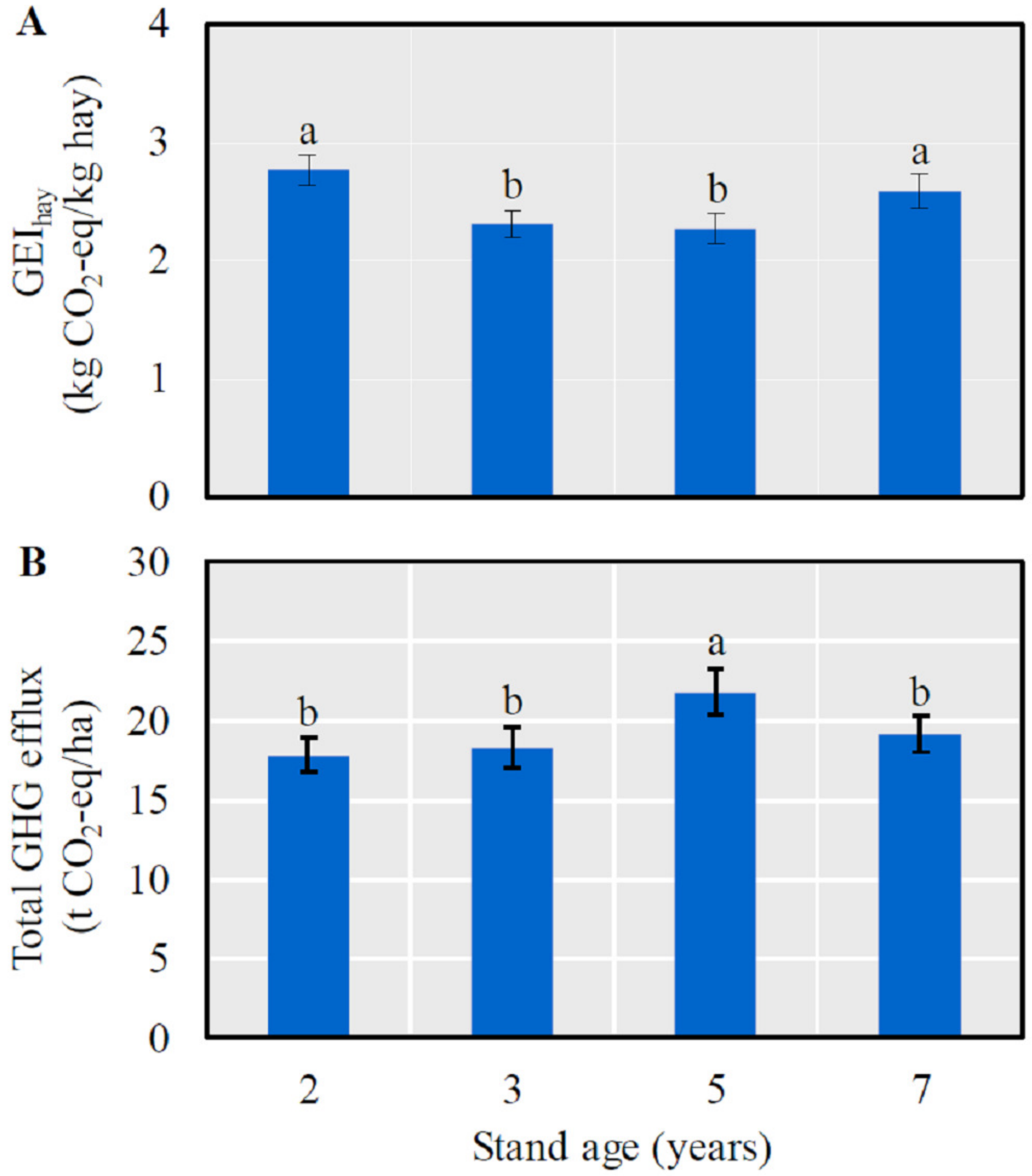
Figure 3

Dynamics of soil temperature (ST) (A), soil water content (SWC) (B), soil organic carbon $(\mathrm{SOC})(C)$, soil total nitrogen (STN) (D), and root biomass (RBM) (E) depending on alfalfa stand age (years, y) and growing season (month, $\mathrm{m}$ ). 


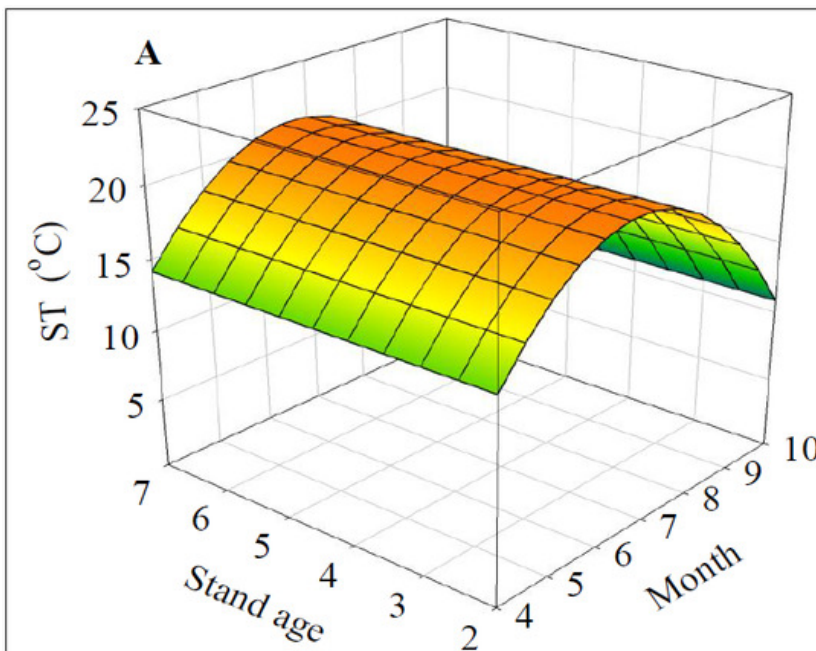

$\mathrm{ST}=-21.84+12.70 \mathrm{~m}-0.96 \mathrm{~m}^{2}+0.03 \mathrm{~m} \times \mathrm{y}$ $R^{2}=0.8807, F_{3,56}=137.78, P<0.0001$

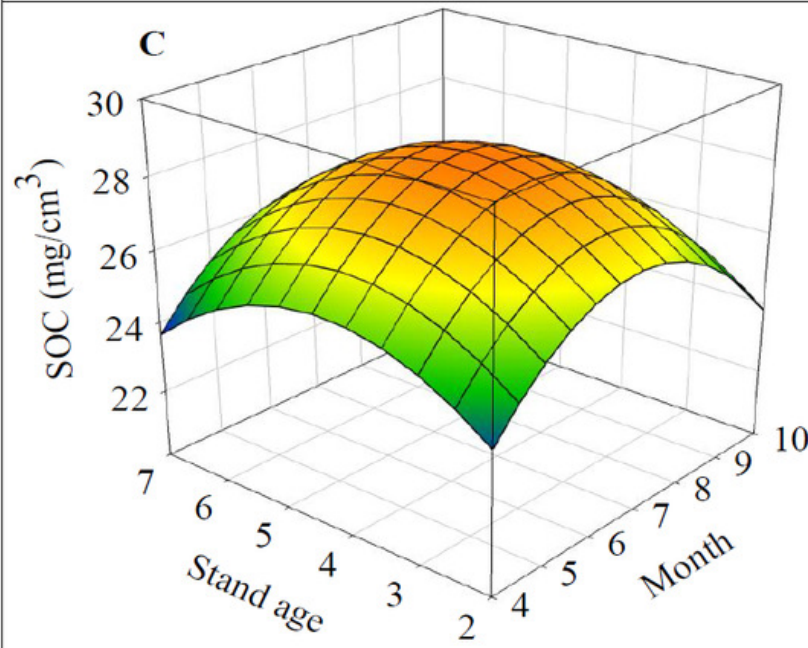

$\mathrm{SOC}=7.66+4.26 \mathrm{~m}-0.31 \mathrm{~m}^{2}+2.76 \mathrm{y}-0.32 \mathrm{y}^{2}$ $R^{2}=0.2634, F_{4,55}=4.92, P=0.0018$

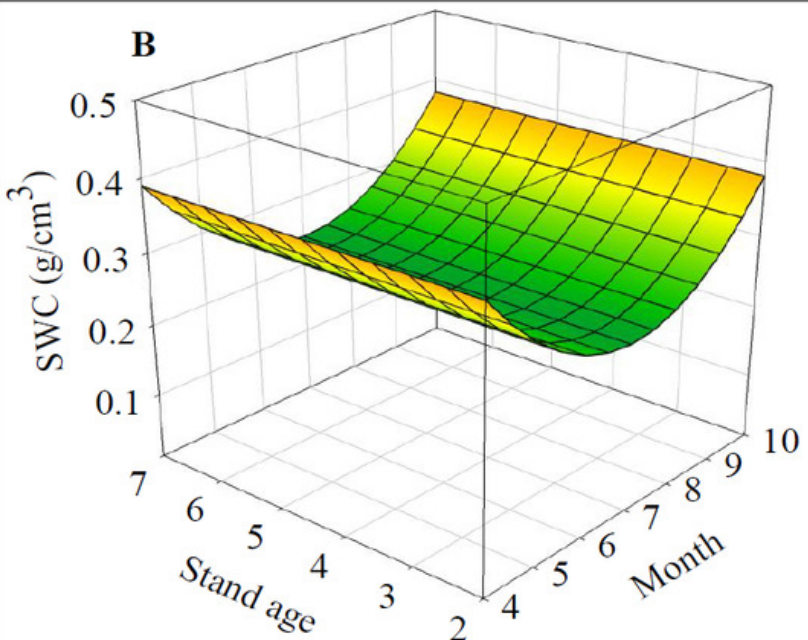

$\mathrm{SWC}=1.04-0.23 \mathrm{~m}+0.02 \mathrm{~m}^{2}$ $R^{2}=0.8469, F_{2,57}=157.76, P<0.0001$

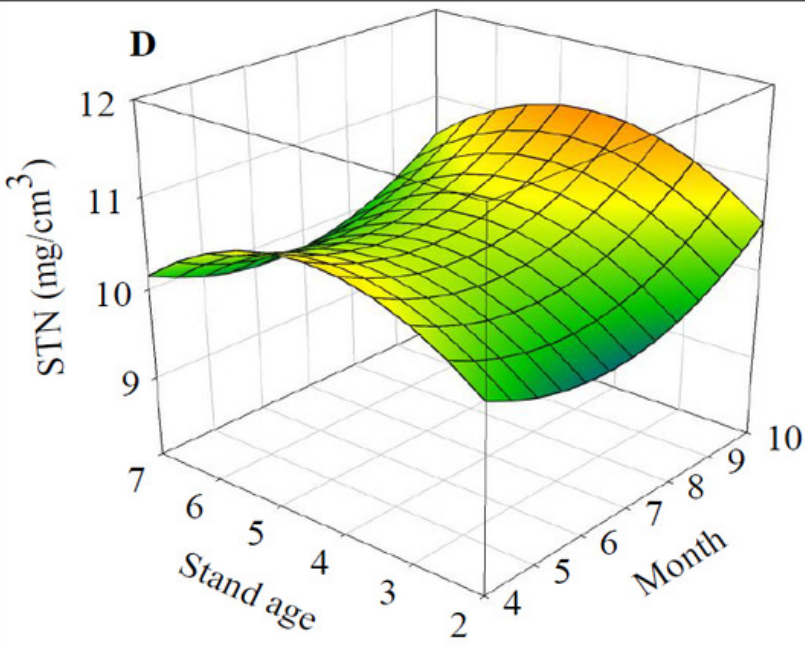

$\mathrm{STN}=10.64-0.79 \mathrm{~m}+0.06 \mathrm{~m}^{2}+1.07 \mathrm{y}-0.12 \mathrm{y}^{2}$ $R^{2}=0.3217, F_{4.55}=6.52, P=0.0002$

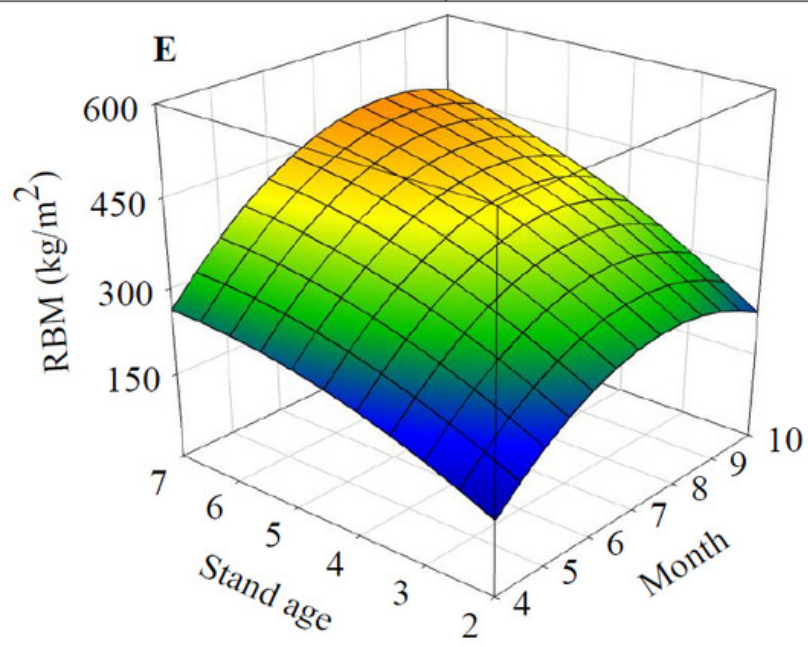

$\mathrm{RBM}=-479.77+164.38 \mathrm{~m}-11.08 \mathrm{~m}^{2}+59.97 \mathrm{y}-5.22 \mathrm{y}^{2}+3.15 \mathrm{~m} \times \mathrm{y}$

$R^{2}=0.9601, F_{5,54}=259.79, P<0.0001$ 
Figure 4

Dynamics of GHG fluxes depending on alfalfa stand age (years, $\mathrm{y}$ ) and growing season (month, $\mathrm{m}$ ): $\mathrm{CH}_{4}(\mathrm{~A}), \mathrm{CO}_{2}(\mathrm{~B})$ and $\mathrm{N}_{2} \mathrm{O}(\mathrm{C})$. 


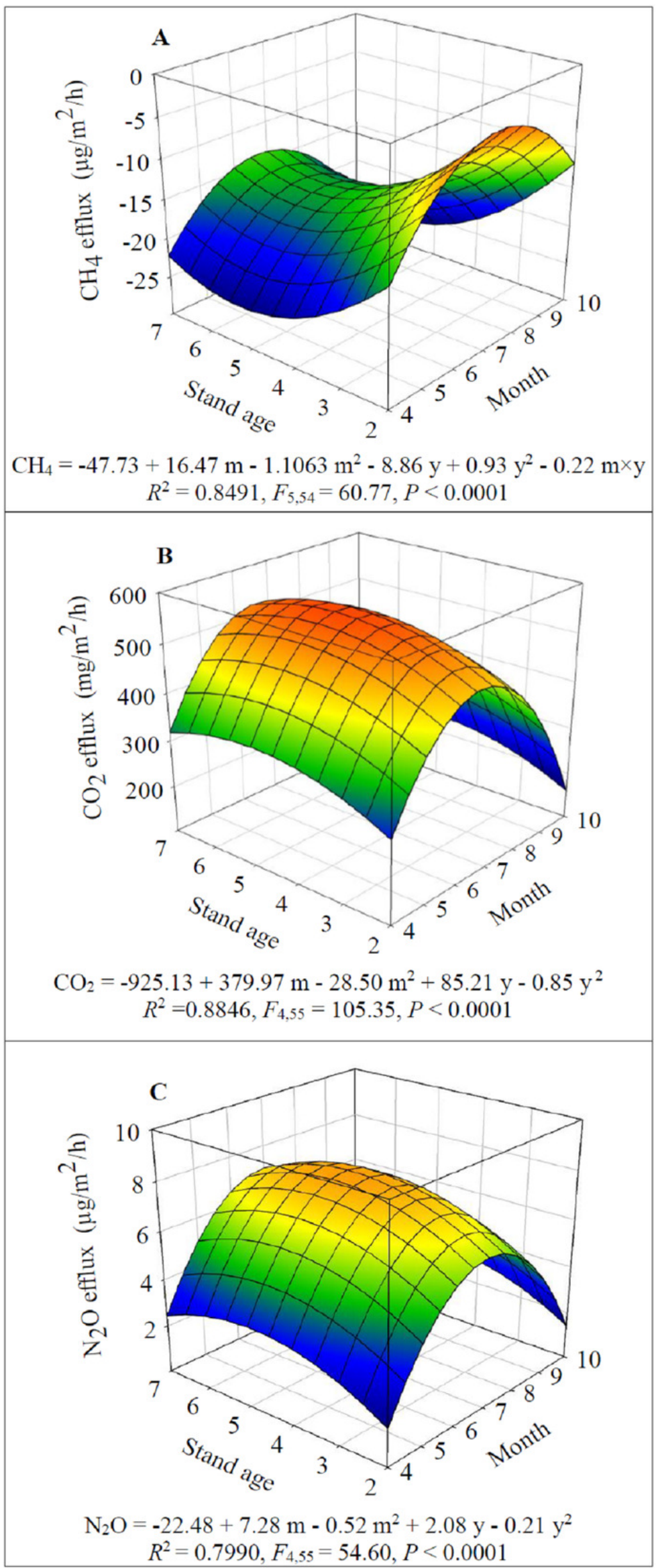

Peer) reviewing PDF | (2019:11:43325:1:1:NEW 17 Jan 2020) 


\section{Table $\mathbf{1}$ (on next page)}

Soil $\mathrm{CH}_{4}$ efflux $\left(\mu \mathrm{g} / \mathrm{m}^{2} / \mathrm{h}\right), \mathrm{CO}_{2}$ efflux $\left(\mathrm{mg} / \mathrm{m}^{2} / \mathrm{h}\right)$ and $\mathrm{N}_{2} \mathrm{O}$ efflux $\left(\mu \mathrm{g} / \mathrm{m}^{2} / \mathrm{h}\right)$ correlated to soil temperature $\left(\mathrm{ST},{ }^{\circ} \mathrm{C}\right)$, soil water content $\left(\mathrm{SWC}, \mathrm{g} / \mathrm{cm}^{3}\right)$, soil organic carbon $(\mathrm{SOC}, \mathrm{mg}$

${ }^{n s}$ non-significant correlation, $*<0.05, * *<0.01, * * *<0.001$. 
1 Table 1 Soil $\mathrm{CH}_{4}$ efflux $\left(\mu \mathrm{g} / \mathrm{m}^{2} / \mathrm{h}\right), \mathrm{CO}_{2}$ efflux $\left(\mathrm{mg} / \mathrm{m}^{2} / \mathrm{h}\right)$ and $\mathrm{N}_{2} \mathrm{O}$ efflux $\left(\mu \mathrm{g} / \mathrm{m}^{2} / \mathrm{h}\right)$ correlated to soil

2 temperature $\left(\mathrm{ST},{ }^{\circ} \mathrm{C}\right)$, soil water content $\left(\mathrm{SWC}, \mathrm{g} / \mathrm{cm}^{3}\right)$, soil organic carbon $\left(\mathrm{SOC}, \mathrm{mg} / \mathrm{cm}^{3}\right)$, soil total nitrogen

$3\left(\mathrm{STN}, \mathrm{mg} / \mathrm{cm}^{3}\right)$ and $\operatorname{root}$ biomass $\left(\mathrm{RBM}, \mathrm{g} / \mathrm{m}^{2}\right)$.

\begin{tabular}{llllll}
\hline $\mathrm{GHG}$ & $\mathrm{ST}$ & SWC & SOC & STN & RBM \\
\hline $\mathrm{CH}_{4}$ & $0.5027^{* * *}$ & $-0.6106^{* * *}$ & $0.3152^{*}$ & $-0.3882^{* *}$ & $-0.1533^{\mathrm{ns}}$ \\
$\mathrm{CO}_{2}$ & $0.8756^{* * *}$ & $-0.8054 * * *$ & $0.5958^{* * *}$ & $-0.3333^{* *}$ & $0.3852^{* *}$ \\
$\mathrm{~N}_{2} \mathrm{O}$ & $0.8186^{* * *}$ & $-0.8200 * * *$ & $0.6210^{* * *}$ & $-0.2573^{*}$ & $0.5077^{* * *}$
\end{tabular}

$4 \quad$ ns non-significant correlation, $*<0.05, * *<0.01, * * *<0.001$. 


\section{Table 2 (on next page)}

The final optimal general linear models (GLMs) and the contribution of factors .

Factors include soil temperature $\left(\mathrm{ST},{ }^{\circ} \mathrm{C}\right)$, soil water content $\left(\mathrm{SWC}, \mathrm{g} / \mathrm{cm}^{3}\right)$, soil organic carbon $\left(\mathrm{SOC}, \mathrm{mg} / \mathrm{cm}^{3}\right)$, soil total nitrogen (STN, $\mathrm{mg} / \mathrm{cm}^{3}$ ) and root biomass $\left(\mathrm{RBM}, \mathrm{g} / \mathrm{m}^{2}\right.$ ) to $\mathrm{CH}_{4}$ flux $\left(\mu \mathrm{g} / \mathrm{m}^{2} / \mathrm{h}\right), \mathrm{CO}_{2}$ flux $\left(\mathrm{mg} / \mathrm{m}^{2} / \mathrm{h}\right)$ and $\mathrm{N}_{2} \mathrm{O}$ flux $\left(\mu \mathrm{g} / \mathrm{m}^{2} / \mathrm{h}\right)$. 
1 Table 2 The final optimal general linear models (GLMs) and the contribution of factors.

\begin{tabular}{|c|c|c|c|c|c|c|}
\hline GHG & Factor & df & Type I SS & Contribution (\%) & $F$ & $P$ \\
\hline \multirow[t]{2}{*}{$\mathrm{CH}_{4}$} & SWC & 1 & 1104.51 & 37.28 & 34.47 & $<0.0001$ \\
\hline & Error & 58 & 1858.44 & 62.72 & & \\
\hline \multirow[t]{4}{*}{$\mathrm{CO}_{2}$} & SWC & 1 & 696778.94 & 64.86 & 224.75 & $<0.0001$ \\
\hline & ST & 1 & 158944.53 & 14.80 & 51.27 & $<0.0001$ \\
\hline & $\mathrm{SOC}$ & 1 & 44915.24 & 4.18 & 14.49 & 0.0004 \\
\hline & Error & 56 & 173616.20 & 16.16 & & \\
\hline \multirow[t]{5}{*}{$\mathrm{N}_{2} \mathrm{O}$} & SWC & 1 & 251.37 & 67.23 & 212.86 & $<0.0001$ \\
\hline & ST & 1 & 16.38 & 4.36 & 13.87 & 0.0005 \\
\hline & $\mathrm{SOC}$ & 1 & 34.43 & 9.21 & 29.15 & $<0.0001$ \\
\hline & RBM & 1 & 6.75 & 1.81 & 5.72 & 0.0202 \\
\hline & Error & 55 & 64.95 & 17.37 & & \\
\hline
\end{tabular}

Final models:

$\mathrm{CH}_{4}$ flux $=3.31-60.11 \mathrm{SWC}\left(R^{2}=0.3728\right)$

$\mathrm{CO}_{2}$ flux $=-29.50-473.10 \mathrm{SWC}+17.45 \mathrm{ST}+10.48 \mathrm{SOC}\left(R^{2}=0.8384\right)$

$\mathrm{N}_{2} \mathrm{O}$ flux $=-2.27-11.98 \mathrm{SWC}+0.24 \mathrm{SOC}+0.21 \mathrm{ST}+0.37 \times 10^{-2} \mathrm{RBM}\left(R^{2}=0.8263\right)$

2 Factors include soil temperature $\left(\mathrm{ST},{ }^{\circ} \mathrm{C}\right)$, soil water content $\left(\mathrm{SWC}, \mathrm{g} / \mathrm{cm}^{3}\right)$, soil organic carbon $\left(\mathrm{SOC}, \mathrm{mg} / \mathrm{cm}^{3}\right), \mathrm{soil}$

3 total nitrogen $\left(\mathrm{STN}, \mathrm{mg} / \mathrm{cm}^{3}\right)$ and root biomass (RBM, g/m²) to $\mathrm{CH}_{4}$ flux $\left(\mu \mathrm{g} / \mathrm{m}^{2} / \mathrm{h}\right), \mathrm{CO}_{2}$ flux $\left(\mathrm{mg} / \mathrm{m}^{2} / \mathrm{h}\right)$ and $\mathrm{N}_{2} \mathrm{O}$

4 flux $\left(\mu \mathrm{g} / \mathrm{m}^{2} / \mathrm{h}\right)$. 